\title{
Vertically Stratified Ash-Limb Beetle Fauna in Northern Ohio
}

\author{
Michael D. Ulyshen, ${ }^{1,2}$ William T. Barrington, ${ }^{1,3}$ E. Richard Hoebeke, ${ }^{4}$ and Daniel A. Herms ${ }^{1}$ \\ ${ }^{1}$ Department of Entomology, Ohio Agricultural Research and Development Center, The Ohio State University, Wooster, \\ OH 44691, USA \\ ${ }^{2}$ Southern Research Station, USDA Forest Service, Starkville, MS 39759, USA \\ ${ }^{3}$ Department of Genetics, North Carolina State University, Raleigh, NC 27695, USA \\ ${ }^{4}$ Georgia Museum of Natural History, University of Georgia, Athens, GA 30602, USA
}

Correspondence should be addressed to Michael D. Ulyshen, mulyshen@fs.fed.us

Received 29 May 2012; Accepted 9 June 2012

Academic Editor: Martin H. Villet

Copyright (C) 2012 Michael D. Ulyshen et al. This is an open access article distributed under the Creative Commons Attribution License, which permits unrestricted use, distribution, and reproduction in any medium, provided the original work is properly cited.

To better understand the diversity and ecology of indigenous arthropods at risk from the invasive emerald ash borer (Agrilus planipennis Fairmaire) in North American forests, saproxylic beetles (Insecta: Coleoptera) were reared from ash (Fraxinus sp.) limbs suspended in the canopy, $\sim 10-17 \mathrm{~m}$ above the ground, and from those placed on the ground in a mature mixed hardwood forest. In total, 209 specimens from 9 families and 18 species were collected from $30.0 \mathrm{~m}^{2}$ of limbs. The generalist cerambycid Neoclytus acuminatus (Fabricius) was the most commonly captured taxon, followed by an assemblage of four exotic ambrosia beetles dominated by Xylosandrus crassiusculus (Motschulsky). Two species largely or entirely restricted to ash, the buprestid Agrilus subcinctus Gory and the curculionid Hylesinus aculeatus (Say), were collected as well. Although there were no differences in beetle richness, abundance, or density between limb positions, community composition differed significantly. This can be largely attributed to phloem and wood-feeding species (i.e., Cerambycidae and Buprestidae) being more common in the suspended limbs and ambrosia beetles being more numerous on the forest floor. Possible explanations for these patterns are discussed.

\section{Introduction}

Saproxylic organisms, species directly or indirectly dependent on dying and dead wood, face numerous anthropogenic threats in many parts of the world. The best studied of these include widespread deforestation and fragmentation, the replacement of complex old-growth forests with younger and more simplified stands, and intensive forest management $[1,2]$. The ever-worsening invasive species problem poses yet another challenge to this beleaguered fauna. One recent example is the emerald ash borer (EAB) (Agrilus planipennis Fairmaire), a phloem-feeding buprestid from Asia responsible for widespread ash (Fraxinus spp.) mortality in eastern North America. This pest was first detected in the Great Lakes region in 2002 [3] and is rapidly spreading into new areas after killing virtually all mature ash trees near its original point of introduction. Thus, much like the previous losses of the American Chestnut and Elm, continent-wide extirpation of the ash genus appears possible. With the window of opportunity to understand the ecology of ash in North American forests quickly and perhaps permanently closing, efforts to better understand faunal communities associated with the genus are of interest.

Although ash is thought to support relatively few arthropod species compared to other temperate deciduous tree genera [4], a number of specialist species are recognized. A recent literature review, for example, revealed that at least 43 arthropod taxa native to North America are dependent on ash [5], nine of which feed on ash phloem or wood. Because extensive surveys of arthropods using ash are lacking, however, this is likely an underestimate of the number of species that will be negatively impacted by the loss of ash [5]. The primary aim of this study was to survey the saproxylic beetle community associated with ash in northern Ohio. We specifically focused on small-diameter ash wood (dead branches) suspended in the canopy as the most likely setting 
to encounter previously-undocumented species unique to that diameter class (see [6]). We also focused on freshlykilled branches as opposed to older substrates as specialist species (i.e., species more likely to be at "high risk" from EAB invasion) are known to be more strongly associated with dying and recently dead wood [7].

Despite the recent expansion of interest in forest canopy biology in both tropical [8] and temperate regions [9], little is known about the ecology of saproxylic organisms high above the forest floor [10]. Most information available on their vertical distribution patterns, for example, comes from flight-intercept trap surveys [11] or other passive collection techniques. Although suggestive, these data provide no information on host-use patterns in the canopy. Such information can only be gained by sampling directly from dead wood, but very few efforts have been made to do so [12-14]. This is particularly true for species associated with small diameter dead wood, a neglected size class even at ground-level [15].

Forest arthropod communities exhibit a high degree of vertical stratification, even in temperate forests [16], and the insect community associated with dead ash limbs are likely to vary with height above the ground. To test this, we sampled beetles from ash limbs placed on the forest floor in addition to those suspended in the canopy in this study. Few such comparisons have previously been made. One of the first was by Vodka et al. [13] who distributed bundles of $<1-12 \mathrm{~cm}$-diameter sections of oak among different settings in the Czech Republic, including some $17-22 \mathrm{~m}$ above the ground in a forest canopy. They collected more species of Buprestidae and Cerambycidae at ground level than in the canopy and concluded that sun exposure was a more important determinant than vertical position. Many species appeared to prefer dead wood placed in the canopy but were not found there exclusively whereas those exhibiting a preference for wood on the forest floor were often restricted to that stratum. Ferro et al. [15] also placed bundles of oak twigs either on the ground, suspended $1.5 \mathrm{~m}$ above the ground, or propped against tree trunks in Louisiana, USA. Beetle richness was greater in the elevated bundles than those placed on the forest floor.

\section{Materials and Methods}

This study took place on NASA Glen Research Center, Plum Brook Station in Erie County, Ohio, USA, a 2600 ha property of considerable ecological value to this highly developed region due to its coverage in meadows, forests, and wetlands [17]. One of the most mature tracts of mixed hardwood forests, located near the northern boundary of the property (Figure 1), was chosen for this study. The forest was dominated by tree genera typical of the region, including Quercus, Acer, Carya, Fraxinus, and so forth. Although the exact age of the forest is not known, all forests on the property were cleared prior to WWII according to Bowles and Arrighi [17]. Nine large-diameter ash trees were selected in the forest. Although an effort was made to choose only living trees, four of those selected had already been killed by the emerald ash borer. In late April 2010, 18 major limbs (each $\sim 4.7 \mathrm{~m}$ in length, see Table 1) were cut from three healthy (i.e., not yet attacked by $\mathrm{EAB}$ ) ash trees growing along the roadside nearby. One limb was suspended as high as possible $(\sim 10-17 \mathrm{~m})$ in the crowns of the nine trees using heavy rope pulled over a limb high above the ground (Figure 2). A second limb was placed directly below the suspended limb at the base of each tree. We returned about three months after the limbs had been distributed. Each limb was cut into $47 \pm 4$ sections (range 31-80) measuring $50.8 \mathrm{~cm}$ in length, bagged, and brought back to the lab. The midpoint diameter of each section was measured to estimate the total bark surface area of the original limb (bark surface area is a more relevant metric than wood volume for early successional faunas primarily restricted to the phloem layer). All the sections from each limb were bundled together and placed in a rearing bag (following [14]) for about 10 months. All emerging beetles were collected and identified to species. Voucher specimens have been deposited in the University of Georgia Collection of Arthropods (UGCA), Athens, Georgia. The Wilcoxon signed rank test was used to compare beetle abundance, density (i.e., abundance/bark surface area), and richness between limbs placed at the two heights. Analysis of similarities was also performed using PAST [18] to compare beetle composition between heights.

\section{Results}

In total, 209 beetles belonging to 9 families and 18 species emerged from the ash limbs (Table 2). These included various phloem and wood feeding species, fungivores, and predators (Table 2). The cerambycid Neoclytus acuminatus (Fabricius) was the most common species collected, accounting for $51 \%$ of all specimens. Nearly $18 \%$ of the beetles collected belonged to one of four species of exotic ambrosia beetles, of which Xylosandrus crassiusculus (Motschulsky) was the most abundant (Table 2). Only two of the species $(\sim 11 \%)$ were represented by a single specimen, suggesting that the local ash-limb beetle fauna was well sampled. Two of the species collected, the buprestid Agrilus subcinctus Gory and the curculionid Hylesinus aculeatus (Say), are known to be largely or entirely restricted to the ash genus. The other species have been recorded from several or many other tree genera (Table 2). Based on the Wilcoxon signed rank test, there were no differences in beetle richness $(P=$ $1.0)$, abundance $(P=0.7)$, or density $(P=0.7)$ between limb positions. Community composition, however, varied significantly between positions based on ANOSIM using both density $(R=0.15, P=0.02)$ and presence/absence $(R=0.21, P<0.01)$ data.

\section{Discussion}

By contrast to Ferro et al. [15] who reared 414 specimens and 35 species from bundles of red oak twigs in Louisiana, we collected only 209 specimens and 18 species from ash limbs despite sampling from about seven times as much wood $\left(\sim 30.0 \mathrm{~m}^{2}\right.$ versus $\left.\sim 4.3 \mathrm{~m}^{2}\right)$. Although regional 
TABLE 1: Characteristics of the trees from which ash limbs were suspended and of the limbs themselves.

\begin{tabular}{|c|c|c|c|c|c|c|c|c|c|}
\hline \multirow[b]{2}{*}{ Tree } & \multirow[b]{2}{*}{ Tree condition } & \multirow[b]{2}{*}{$\begin{array}{l}\text { Tree } \mathrm{DBH}^{\mathrm{a}} \\
(\mathrm{m})\end{array}$} & \multicolumn{4}{|c|}{ Limbs suspended in canopy } & \multicolumn{3}{|c|}{ Limbs on forest floor } \\
\hline & & & $\begin{array}{l}\text { Basal diam. } \\
(\mathrm{cm})\end{array}$ & $\begin{array}{l}\text { Length } \\
(\mathrm{m})\end{array}$ & $\begin{array}{l}\mathrm{SA}^{\mathrm{b}} \\
\left(\mathrm{m}^{2}\right)\end{array}$ & $\begin{array}{l}\text { Height }^{\mathrm{c}} \\
(\mathrm{m})\end{array}$ & $\begin{array}{l}\text { Basal diam. } \\
\quad(\mathrm{cm})\end{array}$ & $\begin{array}{l}\text { Length } \\
(\mathrm{m})\end{array}$ & $\begin{array}{l}\mathrm{SA}^{\mathrm{b}} \\
\left(\mathrm{m}^{2}\right)\end{array}$ \\
\hline 1 & Living & 0.60 & 6.8 & 4.3 & 2.6 & 17.4 & 7.5 & 4.0 & 1.9 \\
\hline 2 & Living & 0.99 & 6.0 & 5.9 & 1.2 & 13.5 & 6.7 & 4.2 & 1.7 \\
\hline 3 & Living & 0.68 & 5.4 & 5.1 & 1.4 & 16.8 & 4.9 & 4.8 & 0.9 \\
\hline 4 & Dead & 0.43 & 6.3 & 4.4 & 1.9 & 10.7 & 8.5 & 4.4 & 2.6 \\
\hline 5 & Living & 0.58 & 6.6 & 5.5 & 1.7 & 10.6 & 8.5 & 4.8 & 2.6 \\
\hline 6 & Dead & 0.45 & 6.3 & 3.8 & 1.5 & 11.7 & 6.3 & 4.2 & 1.1 \\
\hline 7 & Living & 0.51 & 6.1 & 5.9 & 1.8 & 13.9 & 7.5 & 6.0 & 1.3 \\
\hline 8 & Dead & 0.41 & 6.0 & 3.6 & 1.1 & 13.0 & 8.1 & 5.0 & 2.1 \\
\hline \multirow[t]{2}{*}{9} & Dead & 0.57 & 5.0 & 4.6 & 1.1 & 13.7 & 5.7 & 5.1 & 1.4 \\
\hline & Mean \pm SE & $0.57 \pm 0.05$ & $6.0 \pm 0.2$ & $4.7 \pm 0.3$ & $1.6 \pm 0.2$ & $13.5 \pm 0.8$ & $7.1 \pm 0.4$ & $4.7 \pm 0.2$ & $1.7 \pm 0.2$ \\
\hline
\end{tabular}

a Diameter at $\sim 1.3 \mathrm{~m}$

${ }^{\mathrm{b}}$ Total surface area of limb material from which beetles emerged.

${ }^{c}$ Distance between the forest floor and the base of each limb.

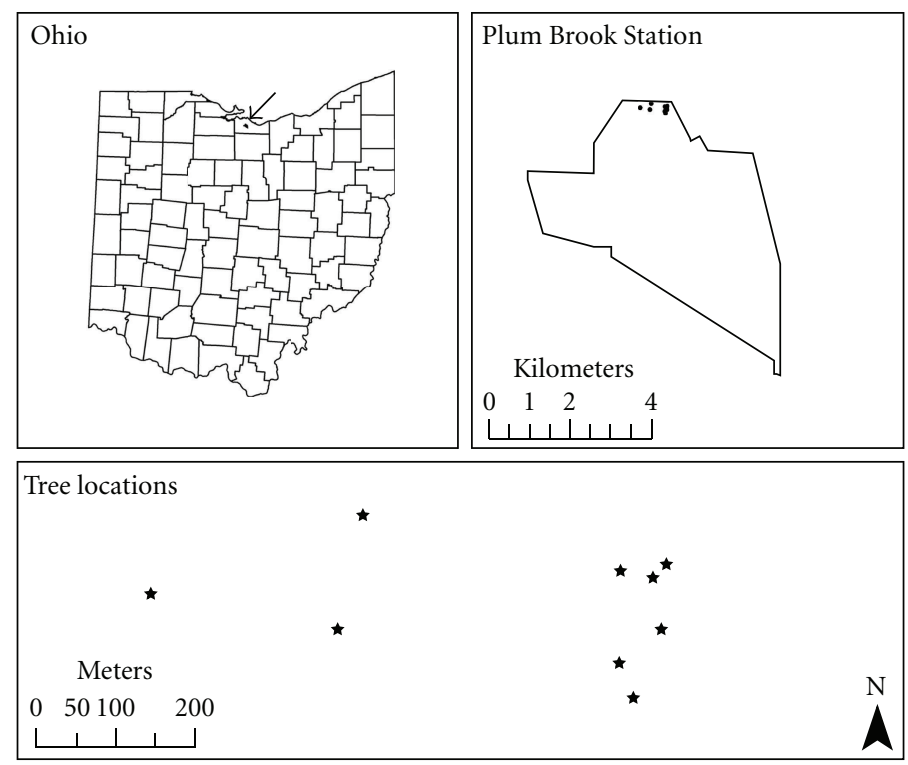

FIgURE 1: Map of study area in northern Ohio, USA.

(e.g., climate, diversity, etc.) and methodological differences (e.g., waiting longer before sampling) between studies were probably important as well, the small fauna reported herein is consistent with the notion that ash supports relatively few species compared to other tree genera. Such differences among host genera have long been recognized, although previous comparisons are based largely on the foliagefeeding fauna. Elton [19], for instance, remarked that despite "being an old native tree, the ash has a rather thin fauna, as can be ascertained by beating its foliage in the summer. There is none of the rich variety of the oak, nor the aphid biomass of the sycamore." Several possible explanations for differences in insect diversity among tree genera were suggested by Southwood [4]. These include how long a genus has been present in a particular region, its abundance during that time and its diversity and relatedness to other genera present. Compared to oaks, for instance, ash has been less diverse and abundant over time and is more taxonomically isolated from other temperate deciduous tree genera [4].

While most of the beetle species collected in this study are generalists with wide host ranges, two of them are known to be largely or entirely dependent on ash (Table 2). Most notably, Hylesinus aculeatus (Say), the eastern ash bark beetle, is restricted to ash and was categorized by Gandhi and Herms [5] as being highly at risk from the emerald ash borer. Although also known to attack Ligustrum, Agrilus subcinctus Gory is another species at high risk from emerald ash borer. This small buprestid beetle is the only native species of 
TABLE 2: Beetle species collected from ash limbs placed on the forest floor or suspended $>10 \mathrm{~m}$ above the ground in a temperate deciduous forest. Asterisks indicate nonnative species and degree symbols represent species not previously reported in association with Fraxinus according to Gandhi and Herms [5].

\begin{tabular}{|c|c|c|c|c|}
\hline Family & Species & Life history & Lower/upper & Total \\
\hline \multirow[t]{2}{*}{ Buprestidae } & Agrilus subcinctus Gory & $\begin{array}{l}\text { Phloem feeder/wood borer of twigs and branches, } \\
\text { restricted to Oleaceae (Fraxinus, Ligustrum) }\end{array}$ & $0 / 4$ & 4 \\
\hline & Chrysobothris sexsignata (Say) & Phloem feeder/wood borer, wide host range & $1 / 3$ & 4 \\
\hline \multirow{2}{*}{ Cerambycidae } & Neoclytus acuminatus (Fabricius) & Phloem feeder/wood borer, wide host range & $38 / 69$ & 107 \\
\hline & Obrium rufulum (Gahan) & Phloem feeder/wood borer, wide host range & $0 / 6$ & 6 \\
\hline Cleridae & Neorthopleura thoracica (Say) ${ }^{\circ}$ & Predator & $1 / 7$ & 8 \\
\hline Corylophidae & Clypastraea lunata (LeConte) ${ }^{\circ}$ & Fungus feeder & $2 / 9$ & 11 \\
\hline \multirow[t]{6}{*}{ Curculionidae: Scolytinae } & $\begin{array}{l}\text { Ambrosiodmus rubricollis } \\
\text { (Eichhoff) }{ }^{* \circ}\end{array}$ & Fungus feeder (ambrosia beetle), wide host range & $4 / 0$ & 4 \\
\hline & Hylesinus aculeatus (Say) & Phloem feeder/wood borer, restricted to Fraxinus & $8 / 2$ & 10 \\
\hline & $\begin{array}{l}\text { Hypothenemus eruditus } \\
\text { (Westwood) }^{\circ}\end{array}$ & Phloem feeder, wide host range & $7 / 0$ & 7 \\
\hline & $\begin{array}{l}\text { Xyleborinus saxesenii } \\
\quad \text { (Ratzeburg)*。 }\end{array}$ & Fungus feeder (ambrosia beetle), wide host range & $0 / 1$ & 1 \\
\hline & $\begin{array}{l}\text { Xylosandrus crassiusculus } \\
\text { (Motschulsky)*。 }\end{array}$ & Fungus feeder (ambrosia beetle), wide host range & $26 / 0$ & 26 \\
\hline & $\begin{array}{l}\text { Xylosandrus germanus } \\
\text { (Blandford)* }\end{array}$ & Fungus feeder (ambrosia beetle), wide host range & $6 / 0$ & 6 \\
\hline \multirow[t]{2}{*}{ Laemophloeidae } & $\begin{array}{c}\text { Cryptolestes ferrugineus } \\
\text { (Stephens) })^{\circ}\end{array}$ & Fungus feeder & $1 / 1$ & 2 \\
\hline & Charaphloeus adustus (LeConte) ${ }^{\circ}$ & Fungus feeder & $4 / 0$ & 4 \\
\hline Passandridae & Catogenus rufus (Fabricius) ${ }^{\circ}$ & Predator & $0 / 3$ & 3 \\
\hline \multirow{2}{*}{ Silvanidae } & Ahasverus advena (Waltl) ${ }^{\circ}$ & Fungus feeder & $1 / 2$ & 3 \\
\hline & $\begin{array}{c}\text { Cathartosilvanus imbellis } \\
{\text { (LeConte })^{\circ}}^{\circ}\end{array}$ & Fungus feeder & $2 / 0$ & 2 \\
\hline \multirow[t]{2}{*}{ Zopheridae } & Namunaria guttulata (LeConte) ${ }^{\circ}$ & Fungus feeder & $0 / 1$ & 1 \\
\hline & Total & & $101 / 108$ & 209 \\
\hline
\end{tabular}

Agrilus known to utilize ash. It specializes on small twigs and was only captured in the suspended limbs in this study. It is also noteworthy that four species of exotic ambrosia beetles were collected, with Xylosandrus crassiusculus (Motschulsky) being captured in high numbers. Because these species are known to utilize a wide range of hosts and appear to be dominating scolytine communities in Ohio [20] and elsewhere in North America [21, 22], they represent another exotic threat (i.e., through competitive interactions) to native saproxylic species.

Although we found no differences in beetle richness, abundance, or density between the two limb positions, community composition differed significantly due to taxonspecific stratification. For example, phloem and woodfeeding cerambycids and buprestids were exclusively or more commonly captured emerging from the suspended limbs than from those on the forest floor, a finding consistent with the results from a flight-intercept trap survey in Georgia [11]. One possible explanation for this is that wood suspended off the ground or exposed to sunlight (see [13]) tends to be drier and therefore less dominated by fungi. Fernandes and Price [23], for example, concluded that gall-forming insects prefer the xeric conditions of the upper forest canopy due to a decreased incidence of fungal disease and parasitism. The same could be true for many saproxylic species. Conversely, species that depend on fungi are likely to focus their activities closer to the forest floor where conditions are more favorable for fungal growth. Our data on ambrosia beetles are consistent with this expectation as these species were exclusively or more commonly captured emerging from the limbs on the forest floor compared to those suspended high above the ground. 


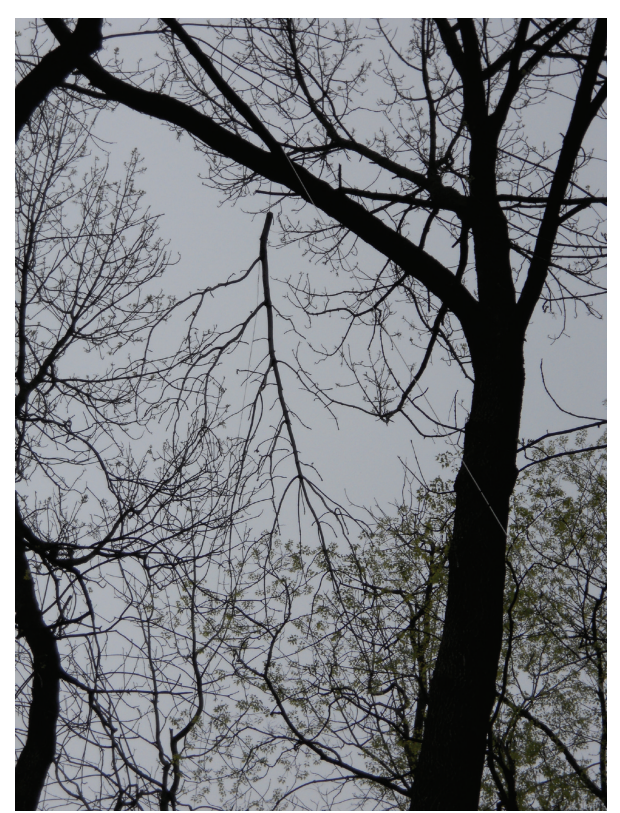

FIgURE 2: An ash limb suspended $17.4 \mathrm{~m}$ above the ground.

\section{Acknowledgments}

The authors thank Rosemary Giesser and Robert Lallier for facilitating research at the NASA Glen Research Center, Plum Brook Station, and Diane Hartzler, Bryant Chambers, Priya Loess, and Dan Rice for assistance with field work. The authors also thank Mike Thomas for confirming Laemophloeidae identifications and an anonymous reviewer for commenting on an early version of the paper.

\section{References}

[1] S. J. Grove, "Saproxylic insect ecology and the sustainable management of forests," Annual Review of Ecology and Systematics, vol. 33, pp. 1-23, 2002.

[2] J. Siitonen, "Forest management, coarse woody debris and saproxylic organisms: fennoscandian boreal forests as an example," Ecological Bulletins, vol. 49, pp. 11-41, 2001.

[3] R. A. Haack, E. Jendek, H.-P. Liu et al., "The emerald ash borer: a new exotic pest in North America," Newsletter of the Michigan Entomological Society, vol. 47, pp. 1-5, 2002.

[4] T. R. E. Southwood, "The number of species of insect associated with various trees," Journal of Animal Ecology, vol. 30, pp. 1-8, 1961.

[5] K. J. K. Gandhi and D. A. Herms, "North American arthropods at risk due to widespread Fraxinus mortality caused by the alien Emerald ash borer," Biological Invasions, vol. 12, no. 6, pp. 1839-1846, 2010.

[6] A. Brin, C. Bouget, H. Brustel, and H. Jactel, "Diameter of downed woody debris does matter for saproxylic beetle assemblages in temperate oak and pine forests," Journal of Insect Conservation, vol. 15, no. 5, pp. 653-669, 2011.

[7] D. W. Langor, H. E. J. Hammond, J. R. Spence, J. Jacobs, and T. P. Cobb, "Saproxylic insect assemblages in Canadian forests: diversity, ecology, and conservation," Canadian Entomologist, vol. 140, no. 4, pp. 453-474, 2008.
[8] Y. Basset, V. Novotny, S. E. Miller, and R. L. Kitching, Eds., Arthropods of Tropical Forests: Spatio-Temporal Dynamics and Resource use in the Canopy, Cambridge University Press, Cambridge, UK, 2003.

[9] A. Floren and B. Schmid, Eds., Canopy Arthropod Research in Europe, Bioform Entomology, Nuremberg, Germany, 2008.

[10] M. D. Ulyshen, "Forest canopies and saproxylic beetles: important habitats for an imperiled fauna," in Advances in Environmental Research, J. A. Daniels, Ed., vol. 6, pp. 529-538, Nova, 2011.

[11] M. D. Ulyshen and J. L. Hanula, "A comparison of the beetle (Coleoptera) fauna captured at two heights above the ground in a North American temperate deciduous forest," American Midland Naturalist, vol. 158, no. 2, pp. 260-278, 2007.

[12] C. Bouget, A. Brin, and H. Brustel, "Exploring the "last biotic frontier": are temperate forest canopies special for saproxylic beetles?" Forest Ecology and Management, vol. 261, no. 2, pp. 211-220, 2011.

[13] S. Vodka, M. Konvicka, and L. Cizek, "Habitat preferences of oak-feeding xylophagous beetles in a temperate woodland: implications for forest history and management," Journal of Insect Conservation, vol. 13, no. 5, pp. 553-562, 2009.

[14] M. D. Ulyshen and J. L. Hanula, "Habitat associations of saproxylic beetles in the southeastern United States: a comparison of forest types, tree species and wood postures," Forest Ecology and Management, vol. 257, no. 2, pp. 653-664, 2009.

[15] M. L. Ferro, M. L. Gimmel, K. E. Harms, and C. E. Carlton, "The beetle community of small oak twigs in Louisiana, with a literature review of Coleoptera from fine woody debris," Coleopterists Bulletin, vol. 63, no. 3, pp. 239-263, 2009.

[16] M. D. Ulyshen, "Arthropod vertical stratification in temperate deciduous forests: implications for conservation-oriented management," Forest Ecology and Management, vol. 261, no. 9, pp. 1479-1489, 2011.

[17] M. D. Bowles and R. S. Arrighi, NASA's Nuclear Frontier: The Plum Brook Reactor Facility, vol. 33 of Monographs in Aerospace History, 2004.

[18] Ø. Hammer, D. A. T. Harper, and P. D. Ryan, "PAST: paleontological statistics software package for education and data analysis," Palaeontologia Electronica, vol. 4, pp. 1-9, 2001.

[19] C. S. Elton, The Pattern of Animal Communities, Methuen, London, UK, 1966.

[20] K. J. K. Gandhi, A. I. Cognato, D. M. Lightle, B. J. Mosley, D. G. Nielsen, and D. A. Herms, "Species composition, seasonal activity, and semiochemical response of native and exotic bark and ambrosia beetles (Coleoptera: Curculionidae: Scolytinae) in northeastern Ohio," Journal of Economic Entomology, vol. 103, no. 4, pp. 1187-1195, 2010.

[21] J. W. Campbell, J. L. Hanula, and K. W. Outcalt, "Effects of prescribed fire and other plant community restoration treatments on tree mortality, bark beetles, and other saproxylic Coleoptera of longleaf pine, Pinus palustris Mill., on the Coastal Plain of Alabama," Forest Ecology and Management, vol. 254, no. 2, pp. 134-144, 2008.

[22] J. W. Campbell, J. L. Hanula, and T. A. Waldrop, "Effects of prescribed fire and fire surrogates on saproxylic Coleoptera in the southern Appalachians of North Carolina," Journal of Entomological Science, vol. 43, no. 1, pp. 57-75, 2008.

[23] G. W. Fernandes and P. W. Price, "The adaptive significance of insect gall distribution: survivorship of species in xeric and mesic habitats," Oecologia, vol. 90, no. 1, pp. 14-20, 1992. 

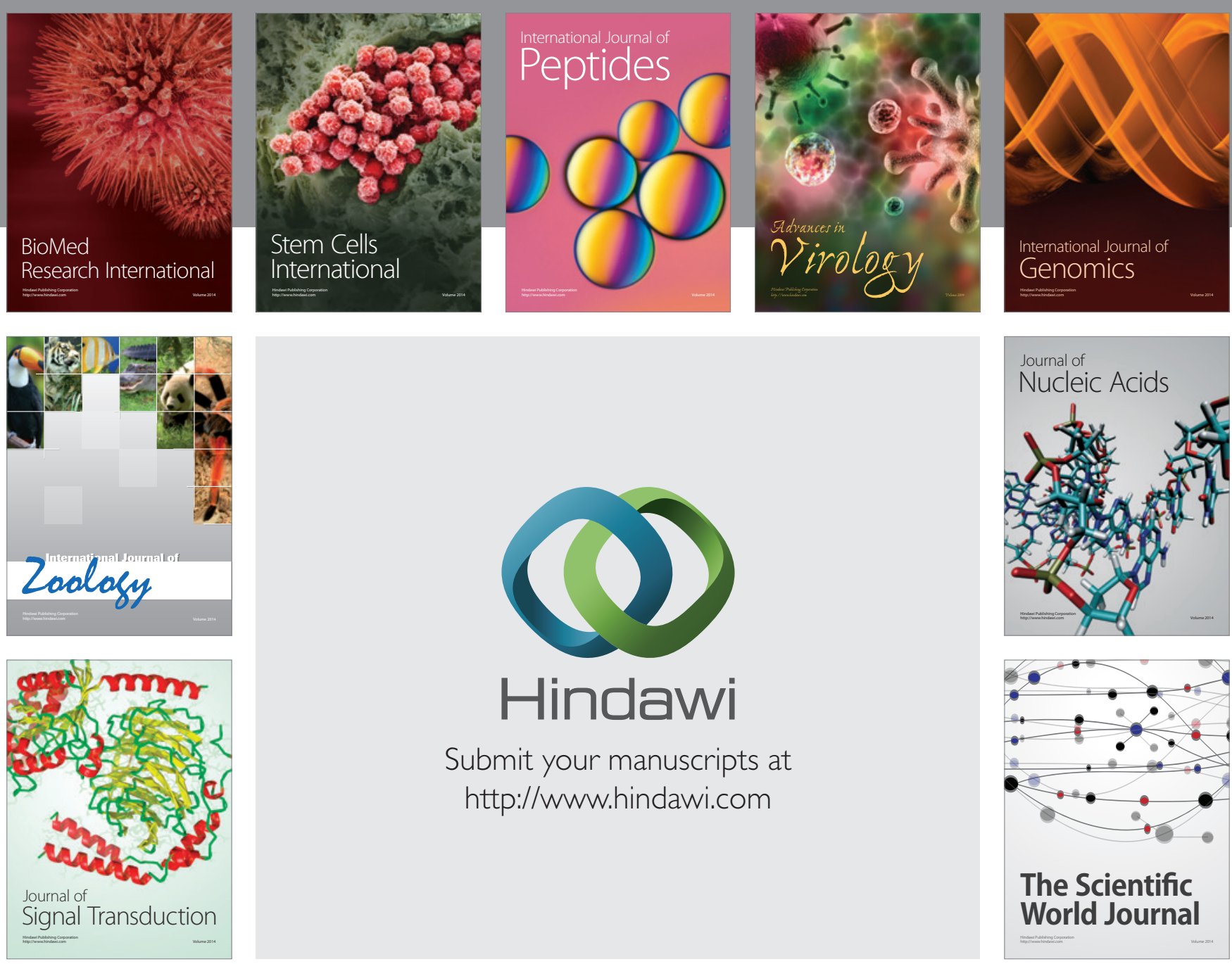

Submit your manuscripts at

http://www.hindawi.com
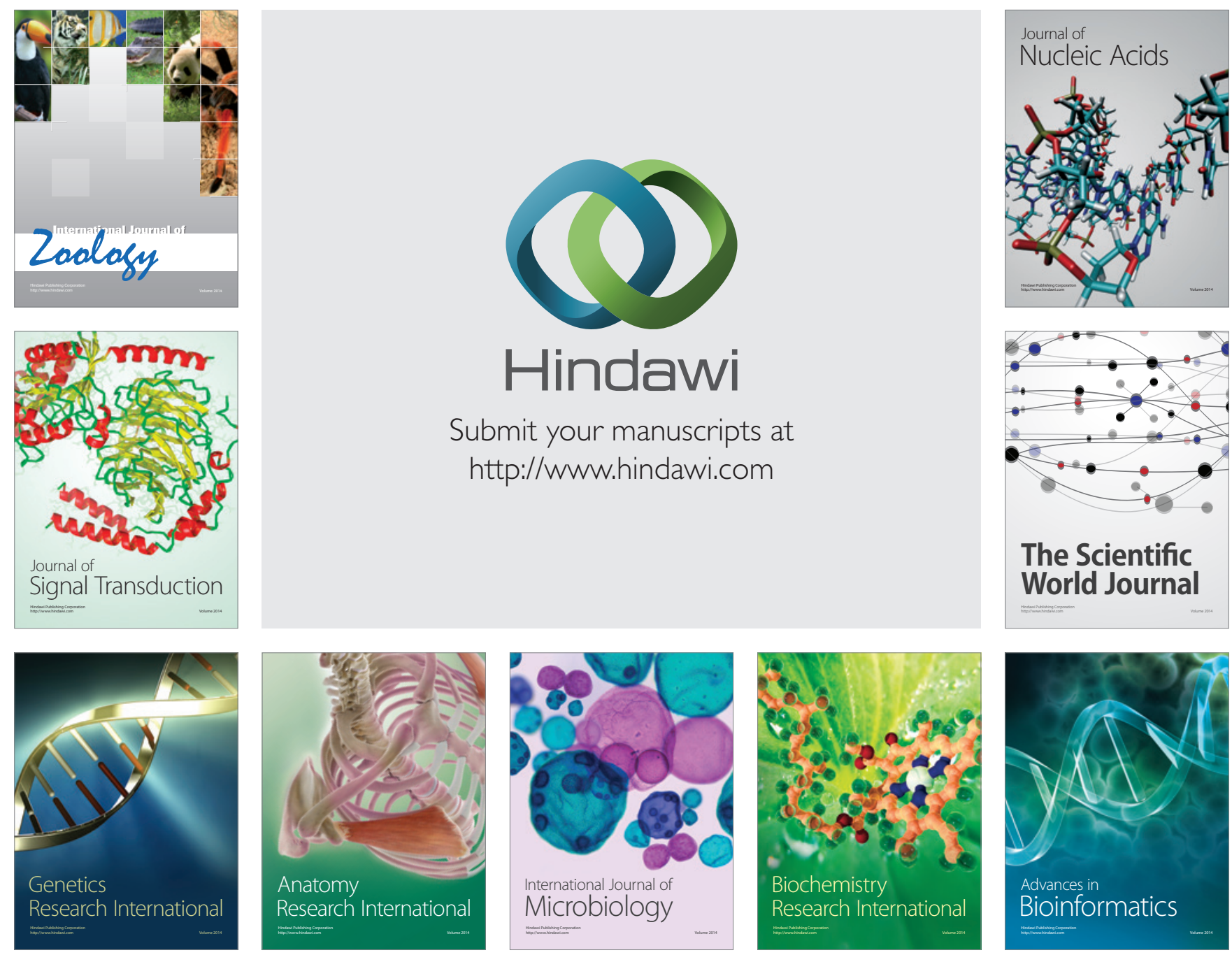

The Scientific World Journal
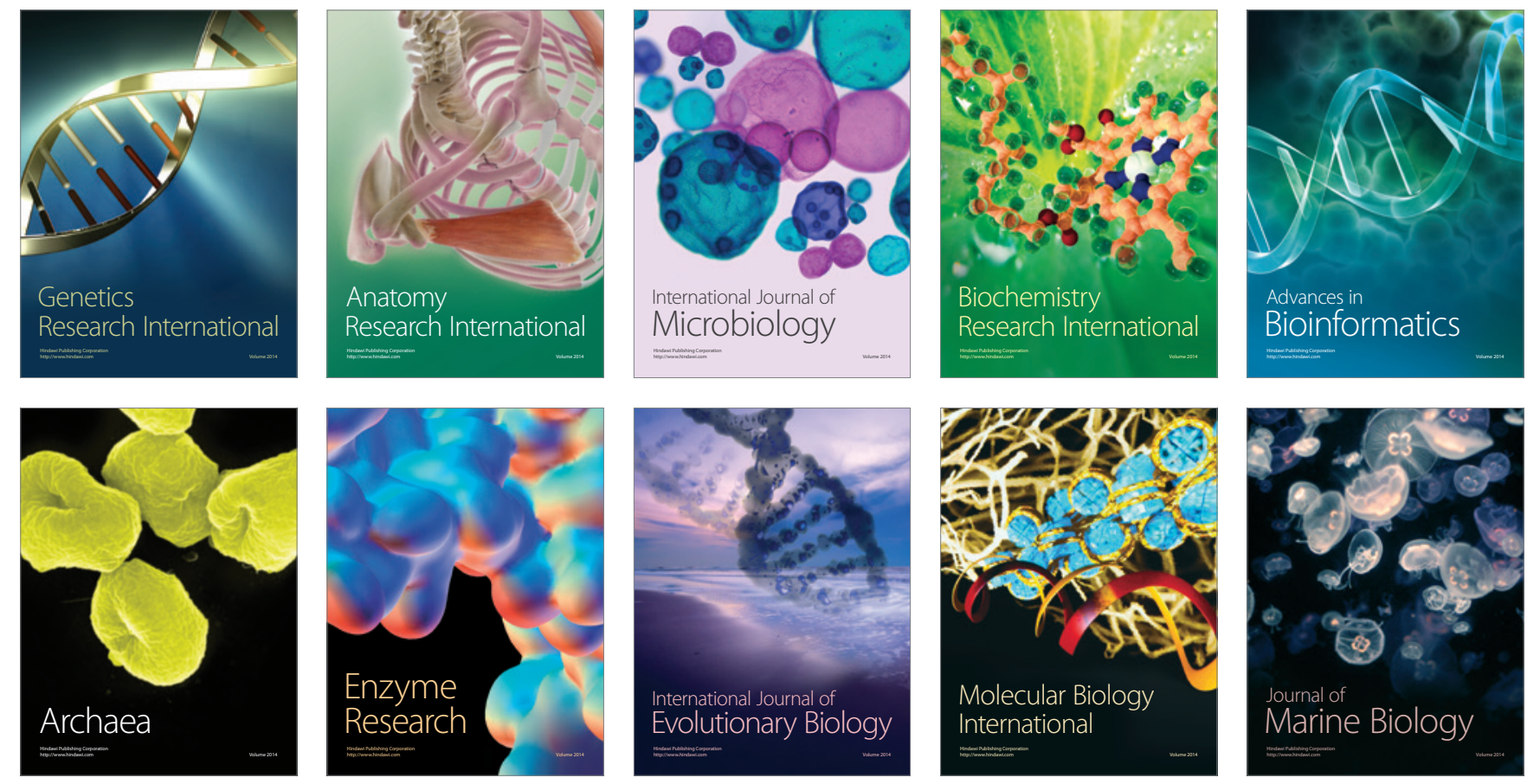